Trinity University

Digital Commons @ Trinity

Health Care Administration Faculty Research

Health Care Administration

Summer 2001

\title{
Private Sector Union Density and the Wage Premium: Past, Present, and Future
}

Barry T. Hirsch

Trinity University

Edward J. Schumacher

TrinityUniversity, eschumac@trinity.edu

Follow this and additional works at: https://digitalcommons.trinity.edu/hca_faculty

Part of the Medicine and Health Sciences Commons

\section{Repository Citation}

Hirsch, B.T. \& Schumacher, E.J. (2001). Private sector union density and the wage premium: Past, present, and future. Journal of Labor Research, 22(3), 487-518. doi: 10.1007/s12122-001-1018-7

This Article is brought to you for free and open access by the Health Care Administration at Digital Commons @ Trinity. It has been accepted for inclusion in Health Care Administration Faculty Research by an authorized administrator of Digital Commons @ Trinity. For more information, please contact jcostanz@trinity.edu. 


\title{
Private Sector Union Density and the Wage Premium: Past, Present, and Future*
}

\author{
BARRY T. HIRSCH \\ Trinity University, San Antonio, TX 78212
}

EDWARD J. SCHUMACHER

East Carolina University, Greenville, NC 27858

\section{Introduction}

The rise and decline of private sector unionization were among the more important features of the U.S. labor market during the twentieth century. Following a dramatic spurt in unionization after passage of the depression-era National Labor Relations Act (NLRA) of 1935, union density peaked in the mid-1950s, and then began a continuous decline. At the end of the century, the percentage of private wage and salary workers who were union members was less than 10 percent, not greatly different from union density prior to the NLRA.

An emerging consensus among industrial relations scholars is that absent a major shift in worker attitudes regarding capitalism, individualism, and the state, accompanied in turn by changes in the legal structure, there can be no rebound in traditional unionization. ' The status quo is not an altogether attractive scenario, however, even for those not enamored with the contribution that unions, in their current form, make to social welfare. More of the same means that in the shrinking unionized sector we retain a system that is overly confrontational and does too little to facilitate value-enhancing behavior among management and unions. More of the same means that employees in most workplaces will have few outlets for collective voice and participation and that companies will be constrained in their ability to promote and facilitate the exercise of voice. And more of the same means continuing a growing reliance on governmental regulation and the courts to set economy-wide workplace standards, reducing the role of enterprise-level bargaining (implicit and explicit) between employers and their work forces.

Our purpose is to examine the relationship between private sector union density and the wage premium, identifying where we have been and where we may go in the future. ${ }^{2}$ The starting point is the fact that labor unions are in decline and now represent a small proportion of the private sector work force. This trend poses a dilemma for society, workers, and public policy. Although the effects of unions in the workplace vary enormously, our reading of the evidence is that on balance unions are detrimental to company performance and economic efficiency. But in addition to unions' negative effects, union representation and collective bargaining provide workers with varying degrees of workplace democracy, collective voice, monitoring of working conditions, 
protection from discrimination, and enforcement of contractual provisions. For the 90 percent of private sector workers who are not unionized, effective worker voice and participation are provided at less than efficient levels. And there is a substantial reliance on governmental regulations and workplace mandates, accompanied by a litigious enforcement process.

There are various reasons why unions are in decline. Herein, we focus on the link between what is surely one of unions' principal functions, raising wages and other forms of compensation, and the consequent decline in their membership and coverage. We conclude that unions (and society) are caught in a cruel paradox. As long as the U.S. remains a competitive, open economy with a decentralized, partially organized collective bargaining system, the attempt by unions to acquire and maintain high wages ensures that the union sector will remain small. Our conclusion is similar to that of Freeman and Medoff (1984, pp. 248-51), who argue that the "monopoly" face of unionism is putting the organized labor movement and "collective voice" out of business. From society's point of view, the monopoly face should be blunted and the voice face emphasized. In a final section of the paper, we conclude that tweaking the current system of labor law is unlikely to accomplish to a satisfactory degree the "less monopoly/more voice" outcome. Rather, we discuss the desirability of a more fundamental shift involving "conditional deregulation" or a change in the default workplace governance structure. The goal of such fundamental reform is to substantially enhance collective voice in the largely nonunion private sector, while at the same time constraining those forms of worker rent seeking deleterious to economy-wide economic performance.

\section{The Decline in Private Sector Union Density: A Summary}

Following peak membership density during the 1950s (Freeman, 1997; Troy and Sheflin, 1985), the percent of private nonagricultural wage and salary workers who are union members stood at 24.6 percent in $1973,16.8$ percent in 1983, and at 9.5 percent in 1999. Private nonagricultural union membership was 14.9, 11.9, and 9.4 million during 1973, 1983, and 1999 (Hirsch and Macpherson, 2000, Table 1c). ${ }^{3}$ In Figure 1, we show union membership and density in the private sector for the years 1973-1999. Readily evident is the steep decline in density during the 1980s, a decline continuing through today, albeit at a slower pace.

As discussed subsequently, some of the union decline is structural, owing to employment shifts out of heavily unionized industries into less unionized ones. Yet one sees a sizable decline within industries as well. Figure 2 shows unionization within the manufacturing sector, as well as the share of total private wage and salary employment accounted for by manufacturing. Manufacturing as a percent of private nonagricultural employment declined from 33.2 percent in 1973 to 19.7 percent in 1999. Union density declined from 38.9 percent in 1973 , to 27.8 percent in 1983 , and to 15.6 percent in 1999 (Hirsch and Macpherson, 2000, Tables 1c-ld). Not only has manufacturing employment become less important over time, but union density within the manufacturing sector also declined sharply over the last quarter century. 
Figure 1

Union Membership and Density, Private Nonagricultural Workers

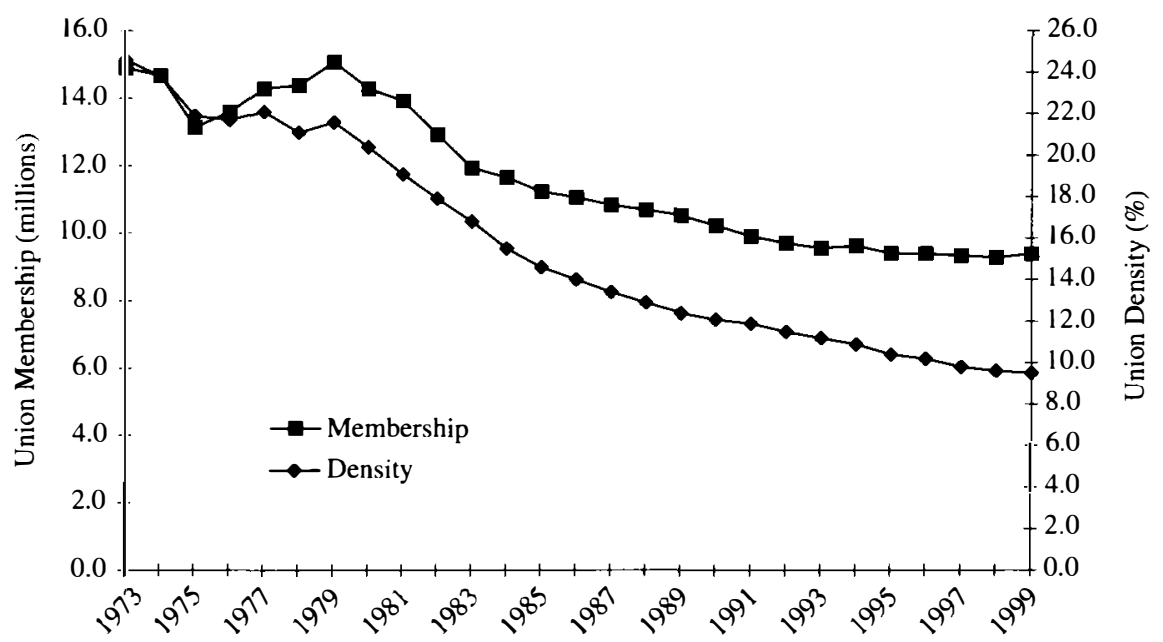

Source: Data are from Hirsch and Macpherson (2000, Table 1c) for the years 1973 to 1999. Union membership is the number of private sector, nonagricultural, wage and salary workers who are union members (in millions). Density is the percentage of private sector, nonagricultural, wage and salary workers who are union members.

An important determinant of changes in union density is the ability of unions to organize new members. Figures 3a and 3b (from Farber and Western, 2000) provide information compiled on the number of NLRB certification elections and the total votes cast in these elections. The number of union representation elections fell suddenly and sharply in the early 1980s, coinciding with President Reagan's firing of unionized (PATCO) air controllers who had gone out on strike. ${ }^{4}$ The number of NLRB union certification elections fell from a level of about 8,000 a year in 1980 to about 4,400 in 1990. The level of election activity declined a bit through the later 1980s and early 1990s, but has increased modestly following the AFL-CIO's emphasis on organizing since John Sweeney became president. Votes cast in these elections fell by more than half over the same period, from about 500,000 a year to just over 200,000 a year. The larger percentage decline in number of votes than elections reflects the declining average size of the election or workplace unit over time.

The news on union organizing is even worse than is evident in the election data. As seen in Figure 4 (Farber and Western, 2000), union win rates in certification elections declined steadily, from a win rate of about 80 percent in 1940 to about 50 percent by $1975 .{ }^{5}$ Since 1975 , the win rate has hovered just at or below 50 percent in most years. Moreover, not only has the average size of election units fallen over time, union win rates are lower in larger workplace units. And this size gap in win rates has 
Figure 2

Union Membership, Density, and Employment, in Private Manufacturing

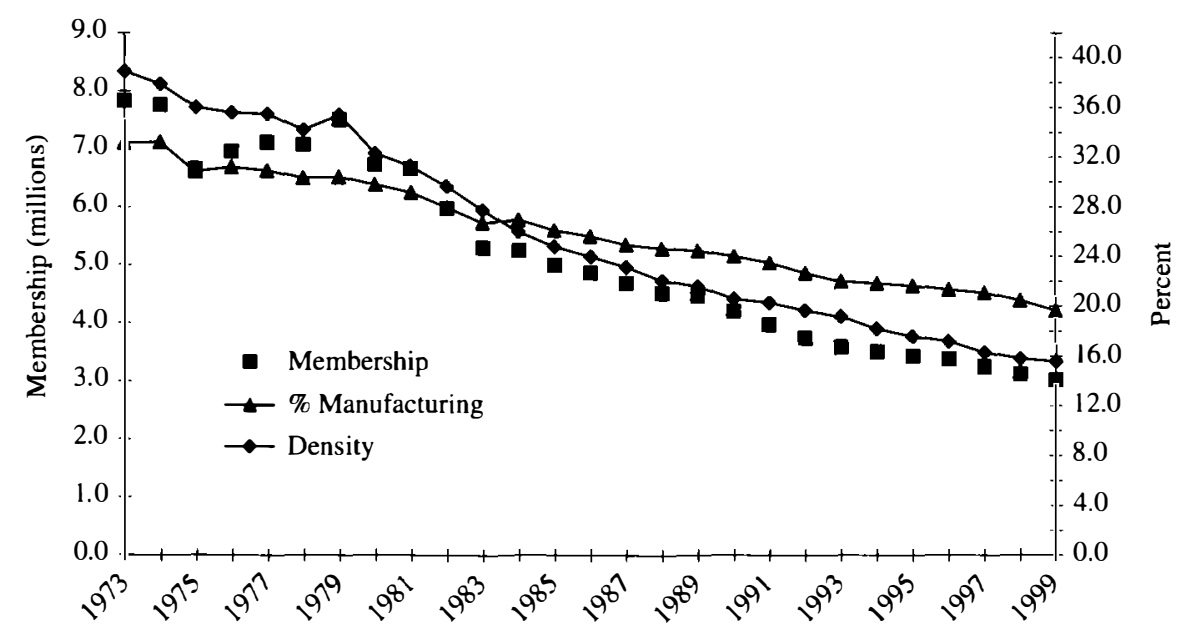

Source: Data are from Hirsch and Macpherson (2000, Tables Ic, Id) for the years 1973 to 1999. Union membership is the number of private sector manufacturing, wage and salary workers who are union members (in millions). Density is the percentage of private sector manufacturing, wage and salary workers who are union members. \% Manufacturing is the percentage of total private nonagricultural employment in manufacturing.

increased over time (Farber, 2001). Although good data are not available, most evidence indicates that even among the union elections wins, fewer have culminated in a first contract between the union and employer. ${ }^{6}$

In short, the number of union elections has declined, the average size of the election unit has fallen, the average win rate has dropped, particularly for large units, and first contracts have become less likely following a union win. Efforts at reversing these trends are underway. But even a substantial increase in the number of new workers organized and first contracts obtained will not stabilize private sector union density at its current level. Private sector union density will continue to decline until it reaches a lower, sustainable level.

\section{Why Has Private Sector Unionism Declined?}

There is no shortage of explanations for why private sector unionism has fallen. Among the reasons given for union decline are: structural change, the response to union wage premiums in an increasingly competitive U.S. economy, increased management opposition, less favorable interpretation and enforcement of labor laws by the NLRB, less positive union sentiment among organizable workers, and the substitution of public workplace mandates and regulation for collective bargaining. 
Figure 3a

The Number of NLRB Certification Elections

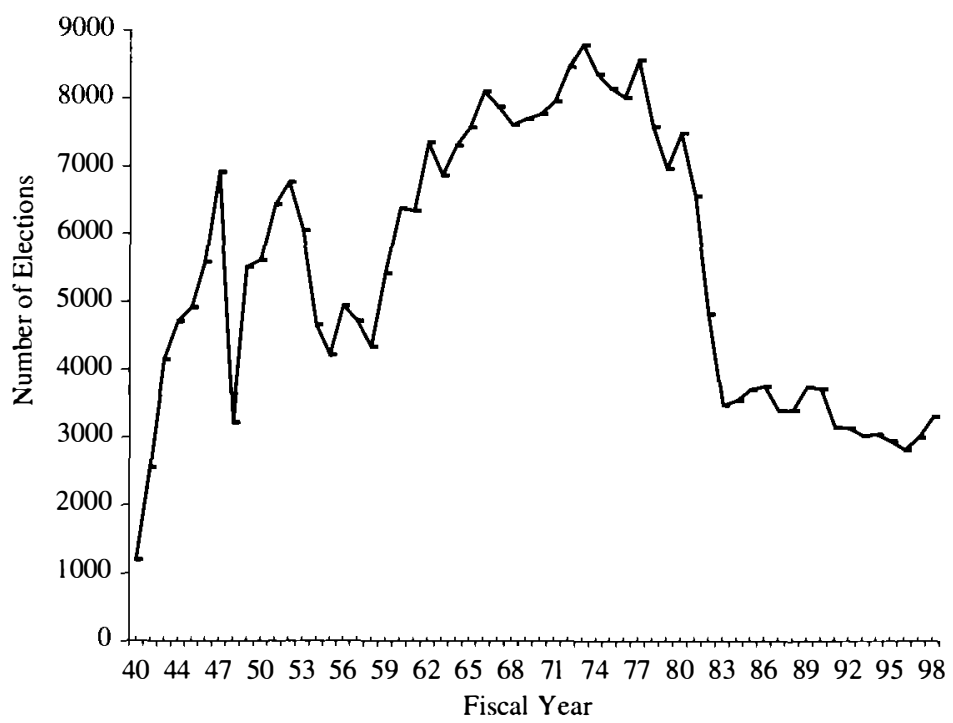

Figure 3b

Total Votes Cast in Elections (in thousands)

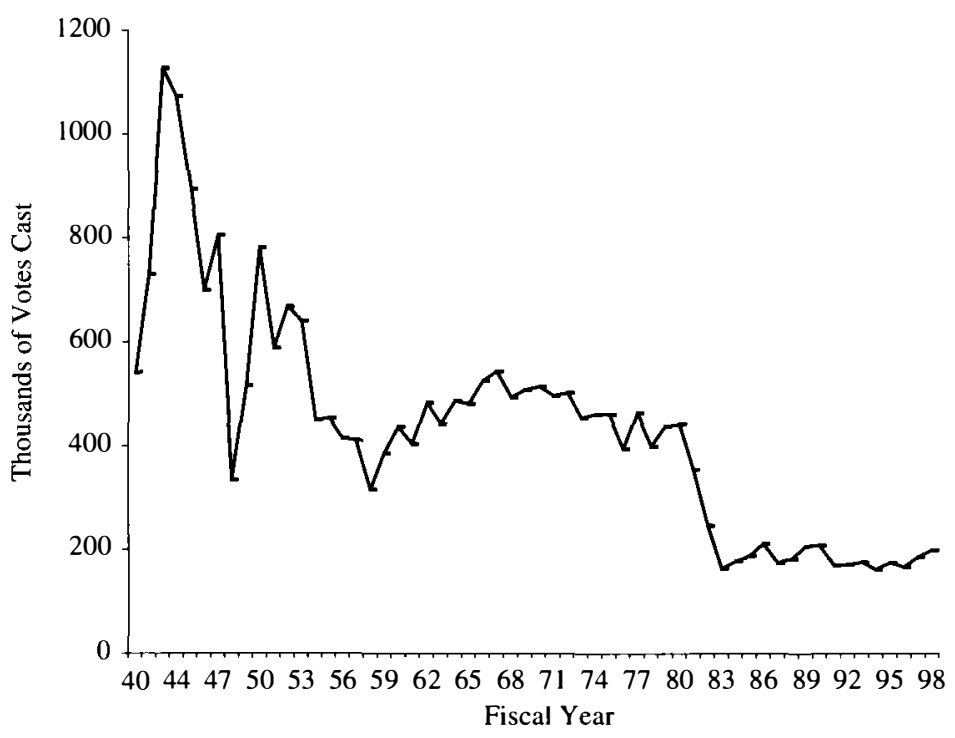

Source: Farber and Weston (2000, Figure 4, p. 9) 
Figure 4

Union Win Rates and Pro-Union Vote Shares in NLRB Elections, 1940-1998

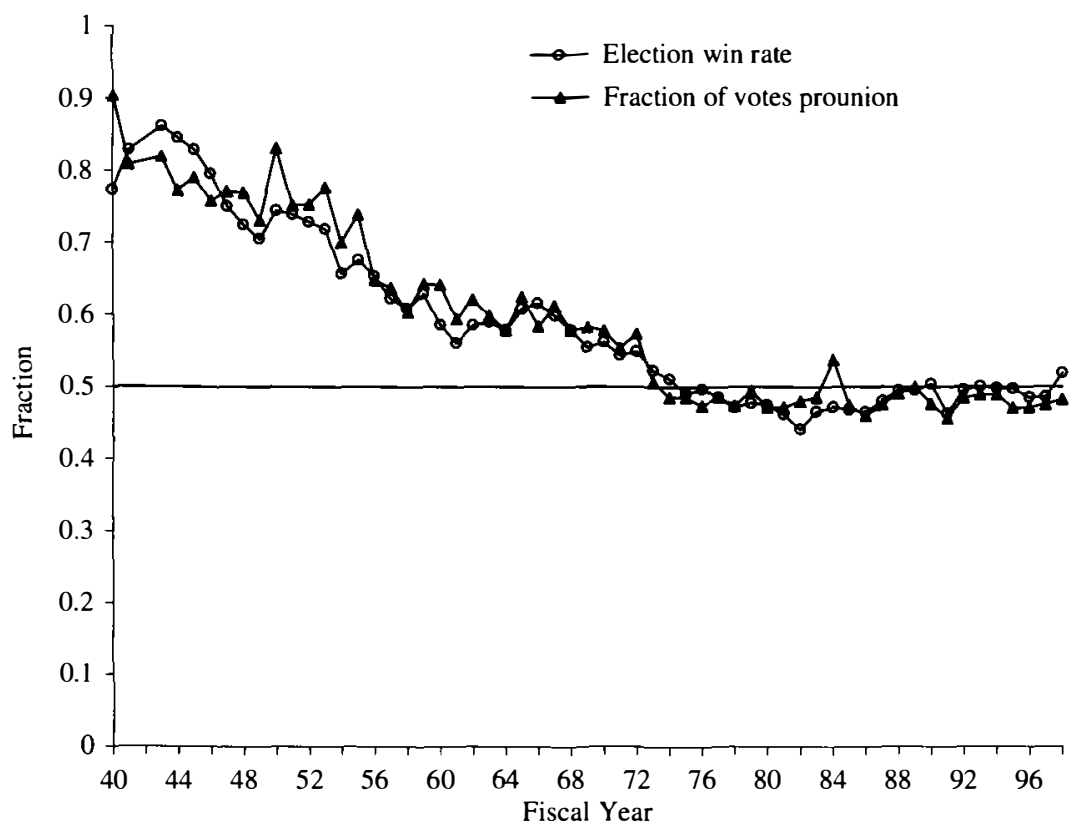

Source: Farber and Weston (2000, Figure 5, p. 10).

Our focus is the relationship between the union wage premium and subsequent union density. The wage premium or, more broadly, the firm's compensation structure is a principal avenue through which unions "tax" firm profits and influence the economic health of firms. As discussed below, several of the explanations for the decline in density (e.g., management opposition, increasing competition) have an economic basis. Union strength not only helps determine wages. Union wages in turn influence union organizing success, company performance and growth, and, therefore, the longrun level of union density.

As seen below, a useful way to analyze changes in union density is an "accounting" stock-flow framework in which changes in density reflect flows into and out of the stock of union and nonunion employment (Dickens and Leonard, 1985; Freeman, 1988; Farber and Western, 2000). Job attrition produces a flow out of union employment. Job growth in existing workplaces provides flows into union and nonunion employment. Job growth taking place in new workplaces is almost entirely nonunion, at least initially. NLRB certification elections and subsequent first contracts lead to flows into union employment, while decertification elections lead to (small) flows out of union employment. 
The various explanations for union decline are not mutually exclusive, and each is plausible. Some work primarily through their influence on employer behavior (e.g., economic competitiveness, most forms of structural change), whereas others influence worker demand for collective bargaining (e.g., union sentiment, the substitution of public regulation). Even taken together, however, these factors may be insufficient to account fully for the fall in private sector unionization. We concur with the view that a broader historical look at the rise and decline of unionism during the twentieth century is needed to understand important social and political forces that shaped both the sudden rise and the gradual but continuous decline of unions (Freeman, 1997; Lipset and Katchanovski, 2001).

Structural Change and Union Organizing. Structural change can include changes in industry and occupation, the demographic structure of the labor force, and the regional location of jobs. By structural change we mean union employment changes due to shifts in labor demand or supply, independent of changes in union wages. Jobs have moved out of heavily unionized manufacturing and into industries such as trade and services with traditionally low union density. Changes in technology have led to smaller employment shares in blue-collar or production jobs and larger employment in nonproduction occupations. Female workers are less likely to be unionized and the share of women in the labor force increased markedly. And substantial employment growth has occurred in the South and Southwest, where union density is traditionally low. Empirically, it is of course difficult to distinguish structural changes affecting union employment from the responses of firms to changes in union wages.

The structural explanation has obvious appeal. Yet it receives surprisingly little support from analysts, who have argued that structural change cannot explain all or even most of the change in unionization. As evidence, authors have pointed to Canada and, to a lesser extent, other countries, which have witnessed structural shifts in industry, occupation, and demographics similar to those in the U.S. Unlike the U.S., Canada and other countries have not seen much of a decline in union density (Freeman and Medoff; 1984; Weiler, 1990; Riddell, 1993). These authors emphasize that the U.S. experience is unique, focusing in particular on management opposition, the rise in unfair labor practices, and organizing difficulties faced by unions given U.S. labor law. Troy (1992, 2000), however, has emphasized that the comparison to Canada is misleading given the importance and growth of the public and quasi-public sectors (e.g., health care) in Canada. If one could isolate Canada's unregulated private sector one would also see a decline in union density, although at a slower rate than in the U.S.

A more direct assessment of the effect of structural change can be obtained using CPS data with worker characteristics. Farber and Krueger (1993) estimate linear probability models showing the probability of union membership, with and without controls for occupation, industry, and individual characteristics, for the years 1977, 1984, and 1991. Structural controls can account for about 35 percent of the union decline between 1977 and 1984, but less than 10 percent of the decline between 1984 and 1991.

Union accounting studies also shed light on the role of structural change, although its precise effect cannot be directly identified. Dickens and Leonard (1985) examine the 
period 1950-1979 and conclude that union decline stems primarily from a fall in organizing and success rates and only modestly from "economic" factors. This approach probably understates the effect of structural change, since part of the decrease in successful organizing is a result of structural changes in industry, occupation, region, and (to a lesser extent) demographics. Dickens and Leonard shift the focus to organizing, finding that it had steadily fallen throughout most of the period and was insufficient to offset the natural attrition rate of union jobs. Note that their study period ended prior to the sharp drop in organizing in the early 1980s. Freeman and Medoff (1984) used a similar framework and predicted (correctly) that private sector union density would fall to a new steady state around 10 percent, given 1970s organizing rates. The lower new organizing rates since the early 1980 s are leading to a new steady-state density below 10 percent.

Farber and Westem (2000) calculate that given current organizing rates and rates of union and nonunion employment growth, steady-state private sector density will be less than 5 percent. ${ }^{7}$ They find that much of the recent decline is fueled by the slow net growth in union relative to nonunion employment. This result lends credence to the structural explanation, although slow net employment growth no doubt reflects other factors, such as increased competitiveness. One way to think about this result is that the steady decline in organizing prior to 1981 is a vital factor in explaining the long-run decline in private sector density. The sharp drop in organizing in the early 1980s ratcheted downward the sustainable rate of private sector union density from some level around 10 percent to a level closer to 5 percent. Farber and Western conclude that even if organizing had maintained its level from the early 1980s, private sector union density would have fallen to a level just 2.5 percentage points higher than it is currently.

Because organizing levels have been so low since the early 1980s, changes in private sector density are most sensitive to differential rates in the net growth of union and nonunion employment. Even substantial increases in new organizing would have rather modest effects on union density. Farber and Western (2000) provide several counterfactual scenarios. What is clear is that to have avoided the decline in union density, new organizing would had to have been far higher than current levels. There is no obvious way that this could have happened. Organizing is costly, and the union base is shrinking. Although new organizing has fallen, organizing expenditures per union member have not. In short, the modest increase in organizing since John Sweeney assumed the presidency of the AFL-CIO has slowed the decline in private sector density, but it has not and probably cannot stop the decline. Absent large unanticipated shif ts in organizing costs and worker support for unions, private sector density should decline further before it reaches a sustainable level.

Union Wage Premiums and the Competitiveness of the U.S. Economy. In order for unions to capture rents for their members, they must either directly increase workplace productivity (beyond what those same workers would produce and earn elsewhere), appropriate some share of owners' surplus stemming from market power of the firm, or tax some portion of the firm's normal returns. Although unionization no doubt leads to productivity increases in many workplaces, on average these effects appear to be close 
to zero, and certainly insufficient to offset wage increases. ${ }^{8}$ In short, wage and compensation premiums are the principal avenue through which unions affect firm profitability, which in turn influences management behavior toward their unions and toward new union organizing. This relationship is discussed more fully in a subsequent section. Ideally, we would like to track over time union effects on profitability and relate this to subsequent changes in union density. Time-consistent data on unions and profitability are not available in standard data sets. But as we see subsequently, we can track union wage premiums over time, thus permitting inferences to be drawn about union effects on firm profitability.

The U.S. economy has also become more competitive over time owing to the increased importance of international trade, changes in technology, and varying degrees of deregulation in highly-unionized transportation industries (airlines, trucking, railroads) and utilities (telecommunications, electricity). The more competitive an industry, the less likely it is to sustain a sizable union premium. Stated alternatively, a given wage premium will have more deleterious employment effects in more competitive environments. In deregulated industries that are naturally competitive such as trucking, union density and wage premiums declined sharply (Hirsch and Macpherson, 1998). In industries such as airlines, where entry is difficult and the union strike threat is substantial, union density and wages have remained high, although decline was evident through much of the 1990s (Hirsch and Macpherson, 2000). ${ }^{9}$

There is surprisingly little work relating union wage gains to subsequent changes in union employment and membership. Linneman et al. (1990) provide evidence that industries with higher wage premiums experience slower employment growth. LaLonde et al. (1996) show a strong negative relationship between union organizing elections and subsequent employment growth. In the literature on unions and company financial performance, union coverage is associated with slower growth, decreased profitability, and lower investment in physical capital and R\&D (for a survey, see Hirsch, 1997). ${ }^{10}$ Although the "union tax" clearly retards employment and sales growth in covered sectors, it does not appear to be associated with higher rates of business failure (Freeman and Kleiner, 1999; Dunne and Macpherson, 1994). Strong unions may push a firm toward the cliff's edge, but they will accept concessions and demonstrate flexibility before pushing it over the edge. ${ }^{1}$

As long as competitive pressures remain strong in the private sector, the prospect for resurgence in union density remains dim. Decreased resistance from management would require a sharp increase in pro-union sentiment among its workers and a shift in unionism's workplace impact away from rent appropriation and toward creation of value added. Such cooperation is unlikely given a collective bargaining framework predicated more on confrontation than cooperation and as long as rank-and-file support for unions depends on their ability to capture rents. Value-added unionism requires innovations and greater flexibility in labor law, among other things, which in turn might facilitate more effective voice and enhanced cooperation between management and labor (Estreicher, 1996). 
Management Opposition and the NLRB. Both union leaders and academic researchers (Weiler, 1990; Freeman and Medoff, 1984; Freeman, 1988) have identified management opposition to organization, unfair labor practices, and unfavorable rulings from the NLRB as important sources of union decline. These issues are difficult to assess. There is little doubt that anti-union sentiment is widespread among U.S. owners and managers of nonunion companies and that business opposition to union organizing has increased over time. Elections are more heavily contested than in the past, unfair labor practices are not uncommon, and fewer union wins culminate in first contracts. It need not follow, however, that changes in managerial opposition account for very much of the decline in private sector density. Anti-union sentiment from business is hardly new, although it appears to have become more respectable as union density has declined. Opposition to organizing is in part the result of union wage premiums and the competitiveness of the economic environment. Even if union wage premiums were constant, management opposition may increase owing to lower levels of unionization among firms' domestic and international competitors. No clear link can be found between the decline in organizing and decisions of the Dotson-led Board during the Reagan administration (Flanagan, 1987; Farber and Western, 2000). Organizing difficulties have not gone away despite a more favorable Board during the Clinton administration. Likewise, private sector union decline began prior to the 1980 s, a decline difficult to link directly to the makeup of the NLRB. ${ }^{12}$

Although union density would no doubt be higher if business opposition were less intense, the fundamental point is that management will continue to oppose union organizing as long as it is economically sensible to do so. It frequently is, particularly in a highly competitive world in which most of one's competitors are nonunion. Although the precise impact of unions on productivity is anything but clear, all evidence points to a negative effect of unions on profits (Addison and Hirsch, 1989; Kuhn, 1998). Stated alternatively, union effects on productivity are not sufficient to offset union wage increases. If unions did not tax profits or if union density were industry-wide, management opposition would be less substantial. It is difficult to imagine a major reduction in management opposition to organizing absent a change in the union impact on the bottom line or a major shift toward more pro-union sentiment among nonunion workers. A shift in worker sentiment regarding unions would directly influence employer behavior during organizing drives and make politically possible changes in labor law and its enforcement.

Worker Attitude and Preferences. Work by Farber (1990) and Farber and Krueger (1992) has concluded that weakened preferences for unionism explain much of the decline over time. Lipset and Katchanovski (2001) measure preferences associated with social democratic or collectivist values, as compared to individualistic values. They conclude that more than in other countries, U.S. workers tend to be far more individualistic and that this perspective helps explain the low levels of private sector density.

The thesis that worker attitudes are an important explanation for the rise and decline of U.S. unionism receives considerable support when one views this over a long historical period. As emphasized by Freeman (1997), unionization in the U.S. occurred 
in large spurts in the late 1930s, following passage of the NLRA in 1935 and its acceptance by the Supreme Court in 1937, and after World War II. Passage of the NLRA and the spurts in unionization were made possible by a sea change in attitudes that occurred during the depression era. Capitalism was seen as inherently unstable, with workers being largely unprotected victims, while collectivist alternatives were seen in a relatively positive light. Although individualism remained very much alive, its prominence was on the wane and far from fashionable. ${ }^{13}$

As argued persuasively by Freeman (1997), it was this shift in attitude that made politically possible passage of the NLRA, guaranteed majority support for unions across thousands of workplaces, and broke down strong management resistance to unions. Business leaders might remain opposed to unions, but they could not wear anti-union sentiment on their sleeves. Once unionization reached a sufficiently high threshold, the deleterious impact of unions on individual firm profitability, growth, and survival was small. In short, the costs of opposing union organizing rose while the economic benefits fell. Following the initial spurts in union growth, there has been a continual longrun decline in density as workers' and voters' faith in capitalism has grown and attitudes have moved once again toward an ethos of individuality. As private sector unionization fell to lower densities, the economic and social calculus for management shifted toward a stronger resistance to union organizing.

The implication of the above analysis is that private sector union density will remain at a low steady state absent a major shift in the public's attitude toward collectivism. Only such a shift would break down management resistance or permit changes in the letter, interpretation, and implementation of U.S. labor law. Neither industrial relations scholars nor we can identify a scenario by which the U.S. private sector would move from a low-density steady state to a high-density steady state. But few observers in 1930 could have predicted the sharp rise in unionism that lay just ahead.

The discussion above emphasizes the individualistic strain running through U.S. public opinion. Although this often translates into anti-union sentiment, such sentiment is far from universal among nonunion workers. To the extent that there is opposition, it is often animus to unionization in its current form. Surveys asking nonunion workers if they would vote for a union in their workplace find considerable support, although not support sufficient to bring it about. Freeman and Rogers (1999) find substantial support among workers for a greater voice and participation in the workplace. But most want that voice to be exercised as part of a cooperative rather than confrontational relationship with management. The 90 percent of private sector workers who are not unionized are not well served by the current system, which of ten offers them a choice between a confrontational unionized labor relations environment or a nonunion governance structure with highly limited opportunities for worker voice and participation.

Government Regulation and Mandates As a Substitute for Unions: Cause or Effect? Coinciding with the secular decline in union density has been an expanded role of government and the courts in providing workers, union and nonunion, with rights and protections in the workplace. Employer mandates and regulations cover such things as 
discrimination, worker safety, overtime hours and pay, pension insurance, notice of plant closings, and family leave. All workers receive "services" or protection that would otherwise have been provided only to workers through the collective bargaining process. As a result, benefits to workers from joining unions have fallen and organizing has become more difficult. An irony here is that unions have been among the strongest proponents of workplace regulation. ${ }^{14}$

It is difficult to assess the impact of government regulations on union organizing, although it seems likely that causation runs in both directions. ${ }^{15}$ Not only has government's increased role in the workplace decreased worker support for unions, the decline in private sector unionism has led to increased public support for workplace regulations. In addition, declining union density has weakened the political influence of organized labor on legislation. Although unions have been notably unsuccessful in gaining legislative victories that apply specifically to labor (union) law, they have had success in pushing for workplace mandates that apply to both the union and nonunion work force (Freeman and Medoff, 1984). The important point here is that there exists a strong demand by the public for many forms of protection in the workplace. The choice is not one between a largely unionized labor market and a largely deregulated labor market. Absent a strong role for collective bargaining or some alternative vehicle for the exercise of worker voice, we must rely instead on a regulated labor market characterized by relatively inflexible rule-making, monitoring, and litigation (Schneider, 1997). The desire among workers for greater voice and cooperation in their workplaces will remain largely unfulfilled.

\section{Union Wage Premiums and Union Density: Theory}

Despite a consensus that union organizing strength in the U.S. labor market has declined, there is not a consensus on how union wage premiums have changed over time. The issue is of some importance. The future course of unionization is tied in no small part to "what unions do." Worker support for unions is predicated in part on their ability to enhance compensation and working conditions, but the magnitude of the wage premium in turn affects current and future employment (membership). The higher the premium the greater will be employment growth in nonunion firms and the stronger will be management resistance to union organizing. Union leaders face the unenviable position of responding to the demands of rank and file for higher compensation, knowing that it will lead to lower employment and membership in the future. If union membership were determined solely by employer actions, maintaining union density at historic levels necessarily would have required a sharp reduction in the wage premium. Taking into account the role of workers, however, it does not follow that lower wage premiums would have been sufficient to avoid union decline. All else the same, lower premiums make workers less willing to join a union and pay union dues. Indeed, a lower wage premium could conceivably decrease density in the long run if the negative effects from a decline in worker support for new organizing were larger than the positive employment effects of employer movement along their labor demand schedules and the reduction in 
resistance to union organizing. Although unlikely, one cannot reject a priori the assertion that current union wage premiums minimize the losses in union membership. ${ }^{16}$

In order to examine the impact of the wage premium on union employment and density, we next consider the predictions from standard union wage models. Although union wage-employment outcomes need not be on the labor demand curve, the standard union monopoly model is a useful starting place (Booth, 1995). The conclusions reached in the standard model are then extended to alternative settings. The analysis applies most directly to firms already unionized, taking into account the profit-maximizing behavior of employers and the wage-employment preferences of union workers. It largely ignores the preferences of nonunion workers for new organizing. As discussed previously, worker support for organizing is a positive function of compensation, while at the same time higher compensation increases management resistance to organizing and decreases profit-maximizing employment levels.

In Figure 5, let $D_{L}$ represent employer demand for union labor, with $W_{c}$ being the competitive wage. The indifference curve $U$ represents the preferences of the union and its willingness to tradeoff wages and employment (membership). A common approach is to treat union preferences as driven by a median voter concerned about the wage and employment. Concern about employment as well as wages derives from the median union worker's own unemployment risk or from concerns about union solidarity and the level of present and future union employment (Booth, 1995). The monopoly union selects a wage $W_{u}$ on $D_{L}$ reflecting its preferred wage-membership mix, subject to the demand constraint (the tangency of indifference curve $U$ with $D_{L}$ ). For our purposes, the important point is that given demand for union labor, there is a negative relationship between the union wage premium and membership. Absent labor demand shifts, we should observe higher union wage premiums associated with declining union density. ${ }^{17}$

Employer demand for labor in unionized markets is likely to have decreased because of increased competitiveness, labor saving technological change, weaker enforcement of labor law, or the like. Such a shift, as shown in Figure 5 by the movement from $D_{L}$ to $D_{L}{ }^{\prime}$, is likely to lead to a wage-employment outcome associated with a lower union wage and employment $\left(W_{u}{ }^{\prime}\right.$ and $\left.\mathrm{E}_{\mathrm{u}}{ }^{\prime}\right){ }^{18}$ To the extent that declining density has resulted from shifting demand schedules for union labor, with little effect on $W_{C}$, we should observe union wage gaps decreasing during a period of declining union density. Alternatively, unions would see larger declines in membership were they to maintain union wage premiums at previous levels. The important point is that if employer demand for union labor is shifting, union density and wage premiums rise or fall together. This positive density-wage relationship contrasts with the effects of a movement along a demand curve, where density and the wage premium are inversely related. ${ }^{19}$

Wage-employment outcomes need not be characterized by the union monopoly model. The "right-to-manage" model (Booth, 1995) maintains the assumption of a settlement on the demand curve, but the position on the demand curve lies between $W_{c}$ and 
Figure 5

\section{Union Wage-Employment Determination \\ On and Off the Demand Curve}

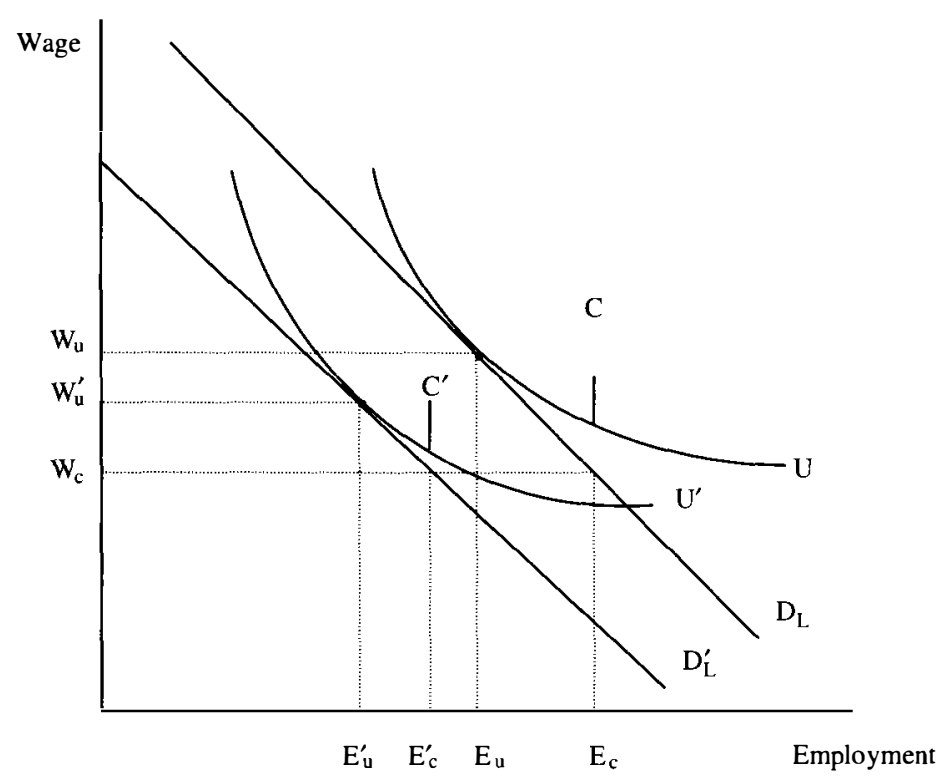

$W_{u}$ and is determined by the relative bargaining strength of management and the union. But the inverse relationship between the union wage and membership continues to hold for any given level of demand, while demand shifts lead to a positive relationship between the wage gap and membership.

Settlements on the labor demand curve are not generally efficient for the parties. That is, there exist settlements off the demand curve with higher employment and lower wages that are preferred by both the union and management. Strong efficiency in bargaining leads to a vertical contract curve $C$ starting at $W_{c}$ with $E_{c}$ employment and a wage above $W_{c}$ off the demand curve. In Figure 5, we draw that portion of the contract curve in which both parties are better off, i.e., outcomes providing a higher union utility than $U$ and a higher firm profit (the portion of $C$ below the isoprofit curve, not shown in Figure 5, that passes through $W_{u}-E_{u}$ ). In the strong efficiency case, there is no inverse relationship between the wage and employment in the short run. In the long run, however, union appropriation of quasi-rents leading to lower investment results in a lower level of future output and employment (Abowd, 1989a). So the inverse relationship between wages and employment results even where contracts are strongly efficient. Decreases in labor demand lead to efficient bargaining outcomes on $C^{\prime}$, implying lower employment and most likely a lower union wage than on $C .{ }^{20}$ It does not follow that 
bargaining can achieve settlements off the demand curve, however, let alone on a vertical contract curve. Evidence is far from clear-cut (Booth, 1995; Kuhn, 1998). Whether union wage-employment outcomes are on or of the labor demand curve, declining demand for union labor should result in a declining wage premium.

To this point, we have considered how movements along and shifts in labor demand curves affect union wages and membership. Changes in union density at the economy-wide or industry level also affect the wage premium. Union wages vary directly with industry density owing to the effects of density on bargaining power and labor demand elasticities. Nonunion wages vary inversely with density owing to labor supply spillover effects and positively with density because of threat effects (Rosen, 1969). During a period of declining density, there is less of a spillover to the nonunion sector and, hence, less downward pressure on nonunion wages. In this case, the unionnonunion wage gap unambiguously declines. Declining union density also decreases the threat of union organizing in nonunion firms, putting downward pressure on nonunion wages. If the union density effect is stronger among union than among nonunion workers, union premiums will decline. If the effects are equivalent among union and nonunion workers, the wage gap will remain unchanged.

Empirical studies typically conclude that there exist substantial threat effects at the industry level, whereas spillover effects are weak, and the positive relationship between wages and industry density is somewhat stronger for union than nonunion workers (Freeman and Medoff, 1981). Based on this evidence, we should expect that during a period of declining density, there exists downward pressure on the union wage gap. ${ }^{21}$

Finally, the relationship between economy-wide union density and an average union wage premium is ambiguous where unionized labor markets are heterogeneous. Demand shifts are likely to have differential effects across labor markets and the average union premium may increase or decrease. For example, increases in international trade are likely to shift labor demand schedules (and change elasticities) differently across markets. Assume that one obtains large losses in union employment in sectors that are highly competitive and union premiums are low, and small employment loss in sectors with high premiums. In this case, declines in union density could be accompanied by an increasing average union premium, even if premiums within all sectors declined or remained the same.

\section{Evidence on Union Wage Gaps, 1973-1999: Rising, Stable, or Falling?}

Although there is general agreement that union wage premiums increased during the late 1970s, there is no consensus as to whether the union premium has been stable or falling since the early 1980s. Blanchflower (1999) estimates union wage premiums from the CPS for 1983-1995. He concludes that the economy-wide union gap has remained relatively constant, with no evidence of a trend. Bratsburg and Ragan (1999) also examine this issue, concluding that there has been little change in the overall union premium, but dispersion in the premium across industries has declined as the U.S. economy becomes more competitive. Hirsch and Macpherson estimate union wage premi- 
ums from the CPS for 1973-1999 using a time-consistent specification. Economy-wide they obtain a union premium estimate of $.172 \log$ points in 1983 and . 140 in 1999, suggesting modest change. For the private sector, however, they obtain estimates of .218 in 1983 and .151 in 1999, a 7 percentage point decline in the union wage premium. Looking at the CPS evidence (from Hirsch and Macpherson) and published data from the Employment Cost Index (ECI), Katz and Krueger (1999, pp. 54-55) conclude that the union wage premium has declined.

Herein we report time-consistent CPS evidence on union wage premium in the private nonagricultural sector, from 1973 through 1999. As discussed above, theory does not provide an unambiguous prediction about the relationship between union premiums and density. Falling density can be accompanied by either a rising or falling wage premium. Based on evidence from the CPS and the ECI, we conclude that the union wage advantage in the private sector has declined over the last 15-20 years. Conclusions about the magnitude of the decline, however, are highly dependent on whether one focuses on adjusted (i.e., regression-based) or unadjusted wage gap estimates and whether one takes into account a bias that results from Census earnings imputation procedures.

The principal data source for our evidence presented here is the Current Population Survey (CPS), the monthly survey of households conducted by the U.S. Bureau of the Census. We summarize evidence presented in a recent paper by Hirsch and Schumacher (2000), who provide union wage gap estimates for private nonagricultural workers from the May 1973-1981 CPS and the 1983-1999 CPS-ORG (outgoing rotation group) monthly earnings files. Logarithmic wage gap estimates are presented unadjusted and adjusted for CPS worker and job characteristics. The adjusted wage gap is simply the coefficient on a union membership dummy variable from a log wage equation with standard controls. ${ }^{22}$ Hourly earnings are defined as usual weekly earnings (inclusive of overtime, tips, and commissions) divided by usual hours worked per week. Top coded earnings (at $\$ 999$ in 1973-1988, \$1,923 during 1989-1997, and $\$ 2,885$ in 1998-1999) are assigned the mean above the cap based on the assumption that the upper tail of the earnings distribution follows a Pareto distribution. ${ }^{23}$ Controls included are years of schooling, potential experience and its square (interacted with gender), dummy variables for gender, race and ethnicity (3), marital status (2), part-time status, region (8), large metropolitan area, industry (8), and occupation (12).

Hirsch and Schumacher's (2000) principal contribution is showing the existence of a systematic bias in some (but not all) types of wage gap estimates owing to the Census hot-deck imputation procedure used for those not reporting eamings. Including workers whose earnings have been imputed by the Census causes a systematic downward bias in union wage premium estimates. The downward bias is large - more than 4 percentage points in recent years. Systematic bias results because union status is not a match criterion used by the Census in selecting an earnings donor. ${ }^{24}$ Most union workers not reporting earnings have their earnings assigned based on a match to a nonunion donor (biasing downward union wages), while some nonunion non-reporters are assigned a union donor (biasing upward nonunion wages). Moreover, Census inclusion 
and delineation of imputed earners in the CPS research and public use files have not been consistent over time, leading to variation in union premium estimates that have nothing to do with actual movements in wages.

Hirsch and Schumacher (2000) construct a time-consistent union wage gap series that nets out the effect of imputed earnings. Where possible, all workers whose earnings have been imputed by the Census are omitted from the estimation sample. In those years (or months) where allocated earners are not reliably identified, wage gap estimates are adjusted to account for the bias. In Figure 6, we present their unadjusted and adjusted wage gap estimates measuring log differentials between union and nonunion private nonagricultural wage and salary workers. The unadjusted gaps are the difference in mean log wages between union and nonunion workers. The adjusted gaps are regression estimates of the log wage differential, with the controls noted above. Both the adjusted and unadjusted CPS estimates net out the effects of workers with imputed earnings.

Figure 6

Union-Nonunion Log Wage Gaps, Private Nonagricultural Sector

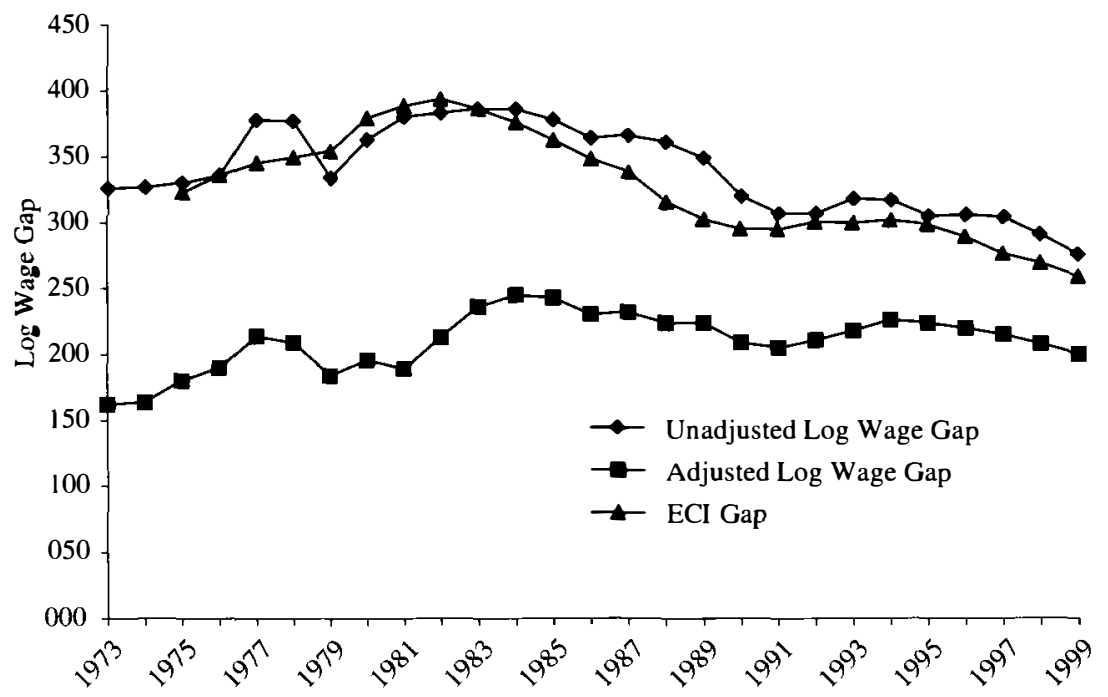

Notes: The Unadjusted and Adjusted Log Wage Gaps are from Hirsch and Schumacher (2000), based on calculations from the May 1973-81 CPS and the 1983-99 CPS-ORG Earnings Files. As described in the paper, all CPS estimates net out a substantial downward bias in union wage gaps resulting from inclusion of workers with imputed eamings. The 1982 figures are the midpoints of 1981 and 1983 . Control variables for the adjusted gap are provided in the text. The ECI Gap is based on the Employment Cost Index for union and nonunion private sector wages. The ECI Gap is set equal to the CPS unadjusted gap in $1983(.386)$. Years prior to and after 1983 represent the log deviations of the union index from its 1983 value, minus the log deviations of the nonunion index from its 1983 value. ECI figures are from Table 7 of the Employment Cost Index, Historical Listing, Bureau of Labor Statistics, July 27, 2000, available at: http://www.bls.gov/ecthome.htm 
Focusing attention first on the unadjusted or raw log wage differential, it rises from about $.33 \log$ points in the early 1970s to about .37 in the late 1970 s and early 1980s. The rise in the differential through 1978 has been noted in much of the previous literature and cited as a source of increased management resistance to union organizing in the 1980s. In the previous literature, the premium is found to drop sharply in 1979 and throughout the early 1980s. As Hirsch and Schumacher (2000) show, much of the apparent decline is due to the fact that the CPS did not report allocated eamings in the 1973-1978 May CPS public use files, but did do so beginning in 1979. Time-consistent treatment of allocated earners indicates that the union gap remained high throughout the mid-1980s. Since the mid-1980s, however, there has been a decline. From a level of $.386 \mathrm{log}$ points in 1983 (the first year of the monthly CPS earnings files), the differential has decreased a considerable $.11 \log$ points — to .276 in $1999 .{ }^{25}$

Turning our attention to the adjusted union-nonunion wage differential, one sees a similar qualitative pattern. The private sector union premium reached a high in the 1983-1985 period. From a level of .236 log points in 1983 and a high of .245 in 1984, the premium declined to about .21 in the early 1990s, rose a bit in the mid-1990s, and then declined to .200 by 1999 , an overall decline of about .04 log points. Although decline in the premium is clearly evident, it is small and far less marked than the sizable $.11 \log$ point decline evident in the unadjusted wage series between 1983 and $1999 .{ }^{26}$

The difference between the adjusted and unadjusted wage gap estimates implies that over time the average private sector union worker's bundle of measurable characteristics (e.g., schooling, demographic characteristics, broad occupation, etc.) has fallen in value relative to the average nonunion worker's bundle. Hence there has been far less change in regression estimates of the union wage differential than is evident in union and nonunion wage rates unadjusted for measurable characteristics. Changes in gender are likely to be particularly important. The proportion of union members who are women has increased steadily over time. The increased frequency of female union members pulls down the unadjusted wage gap, whereas it has little effect on the adjusted gap since sex is included as a control variable (in effect, female union members are compared to female nonunion workers, and vice-versa).

Because of the difference in conclusions reached about the time pattern of the union wage premium based on the CPS, it is useful to look for evidence from data sources other than the CPS. Unfortunately, such a comparison is not conclusive since overall wage trends in the CPS have differed from wage growth in the National Product Accounts (NIPA) and the BLS Employment Cost Index (ECI). Moreover, the exact sources of the differences in the alternative wage series are not well understood (Bosworth and Perry, 1994; Abraham et al., 1999; Krueger, 1999).

The ECI is a quarterly compensation survey administered by BLS, whose units of observation are jobs (occupations) within establishments, which in turn are cross classified by union status (among other things). We examine the ECI wage series for all private sector union and nonunion jobs. The ECI indices have fixed weights across jobs, so changes should not reflect variation over time in the occupation or industry compo- 
sition. The ECI, however, does not account for changes in worker characteristics (schooling, age, gender, etc.). The trend in the ECI union-nonunion log wage gap is shown in Figure 6, with the ECI gap set equal to the unadjusted CPS gap for 1983. The $\mathrm{ECI}$ indicates substantially slower growth in union than in nonunion wages. Over the 1983-1999 period, the slower growth in union wages implies a narrowing of the log wage differential by approximately $.127 \log$ points, or an average eight-tenths of one percent a year. ${ }^{27}$ This is reasonably close to the .11 log point drop in the unadjusted CPS differential, but greatly exceeds the modest $.04 \log$ point decline in the adjusted wage premium. What appears obvious from this comparison is that the ECI indices, while holding constant the job structure, do not account for relative changes in worker characteristics. These characteristics do affect CPS regression-based wage gap estimates.

To gain further insight into what is driving the differences in CPS and ECI wage changes, we examine (results not shown) whether changes in the aggregate CPS figures result primarily from changes in industry employment, or from wage changes that are roughly equivalent across broad industries. Such analysis is interesting in its own right, since unionized labor markets need not be homogeneous. Our conclusion is clear. In the CPS, disaggregation into seven broad private nonagriculatural sectors indicates that little of the decline is accounted for by employment shifts. Holding constant employment shares at 1973 levels but allowing wages to change, we obtained a pattern highly similar to that seen when both employment shares and wages are allowed to change. Similarly, there was little change in the wage premium when we held industry wage premiums constant, but allowed employment weights to change. ${ }^{28}$

Ultimately, we are unable to fully resolve differences between the ECI and CPS in either the timing or the extent of change in the union-nonunion wage differential. It is safe, however, to conclude that wage growth since the early 1980s in the unionized sector has been less than in the nonunion sector and, accordingly, the union wage premium has fallen. Whether the decline in the premium is rather modest, as indicated by CPS regression estimates, or more substantial, as indicated in ECI and unadjusted CPS figures, remains unresolved. We lean toward the conclusion that the decline has been modest, based on CPS wage gap estimates accounting for worker characteristics.

Uncertainty about the magnitude of the union wage gap decline introduces a degree of ambiguity into our interpretation of what has been happening in U.S. labor markets. As argued previously, the simultaneous decline in union membership and relative wages can be explained by inward demand shifts of the union labor demand curve (Figure 5). If the decline in the union wage gap is substantial, as suggested by the ECI or unadjusted gap, it is consistent with unions attaching a relatively large weight on employment, permitting the gap to narrow in order to avoid even further losses in membership. We believe it is more likely that narrowing of the union gap since the mid1980 s is modest, as seen in the CPS regression-based estimates. A roughly 4 percentage point narrowing of the wage gap from a historically high level suggests that unions (and their members with median preferences) have placed a high weight on maintaining their relative wage advantage, despite the concomitant loss in membership. 
Union emphasis on maintaining real wages also helps explain why the union premium rose during the late 1970 s and early 1980 s, despite declining private sector density. The suggestion is that a majority of the rank and file did not fully recognize how strong were the competitive pressures facing unionized companies, or did recognize these pressures and were willing to sustain substantial membership losses in order to maintain wages. ${ }^{29}$ Because economy-wide wage growth was slow during this period, particularly for male production workers, it is hardly surprising that there was not stronger political support within unions for extensive wage concessions. Ultimately, maintaining high wage premiums translated into larger membership losses than would have occurred had wage concessions been more substantial.

An increasingly competitive economy during the 1980s and 1990s and greater nonunion competition facing unionized companies not only shifted labor demand, but also increased the elasticity of demand for union labor. The worsening trade-off between wages and employment eventually resulted in moderate restraint among labor unions and the narrowing union wage gap evident since the mid-1980s.

\section{No Unions, New Unions, or Beyond Unions?}

In the future we will see a continuing decline in private sector union density, to a level below the 1999 rate of 9.4 percent ( 9.5 percent among private nonagricultural workers). Despite modest narrowing in union wage premiums since the mid-1980s, they remain sizable so that union companies are less profitable than they would be absent a union tax. In what is a highly competitive market environment, most nonunion establishments will continue to actively oppose attempts at union organizing.

Continuation of current trends means that workers' desire for voice in the workplace, cooperation with management, and participation in decision making will remain unrealized for much of the largely nonunion work force. There is likely to be a continued reliance on government regulation and mandates in the workplace, a system that is insufficiently flexible and overly litigious. Proposed labor law reforms could provide a modest boost to union organizing and slow the current decline, but moderate increases in new organizing will not boost union density above current levels. Labor law reforms could improve faimess and mitigate the contentiousness of the union organizing process. ${ }^{30}$ The case for labor law reforms that substantially facilitate union organizing, however, is weakened by what we believe to be on balance a deleterious impact of unions, in their current form, on long-run economic performance. We would encourage reforms within the union sector that might discourage rent seeking while enhancing voice. ${ }^{31}$ But such reforms will have at most a modest effect on the steady-state level of union density. In short, it is difficult to envision changes in labor (i.e., union) law that will substantially improve workplace governance for the more than 90 percent of private sector workers not directly affected.

The description above is our best prediction for what the future holds. It is largely a description of the status quo, with the addition of modest reforms in labor law and a growing role for government in workplace regulation. This is not an altogether gloomy 
scenario. As long as workplace regulations do not become unduly onerous, such a future would permit continued economic growth and an improvement in workers' standard of living. The economic pie would get larger and competition among employers in the labor market would ensure that most workers receive shares of the pie roughly commensurate with their economic contribution. But such a labor market will produce a less than optimal level of worker voice and participation (Levine and Tyson, 1990; Freeman and Lazear, 1995; Kaufman and Levine, 2000). In principle, we should be able to do better. For this reason, we focus attention on proposals that might enhance voice among nonunion workers. Whether beneficial changes can be identified and subsequently adopted via our political process, however, is questionable.

Value-Enhancing Reform in Workplace Governance. In the remainder of the paper, we briefly discuss the shape that value- or welfare-enhancing reforms might take. A prerequisite for such a discussion is to identify the criteria that desirable labor and employment law reforms should satisfy. We offer the following. Reforms: (1) should be value enhancing for the parties and the economy; ${ }^{32}(2)$ should involve a greater role for voice within nonunion as well as union workplaces; (3) should encourage cooperation between management, supervisors, and line workers; (4) should allow for variation across heterogeneous workplaces; (5) should be flexible within workplaces over time; and (6) should limit the rent seeking goals of unions (or other worker associations) while enhancing provision of voice.

Absent major reforms, it is difficult to see how the current system can evolve toward an employment governance structure embodying these six characteristics. Keeping in mind the criteria listed above, we discuss below two general approaches that have the potential to be value enhancing. The first approach is termed conditional deregulation, while the second involves a change in the labor law default from no union to some alternative state. In each of these cases, a move away from a default governance structure within the firm or the default regulatory structure requires approval of both management and workers. The requirement for mutual agreement encourages development of value-enhancing alternatives, as compared to the default structure. It is not our purpose to provide detailed proposals for these or other changes in employment law and industrial relations. Rather, we briefly outline general approaches that we believe might lead in the right direction.

Conditional Deregulation. We find particularly attractive changes along the lines suggested by Levine (1995), who proposes a system of conditional deregulation. Levine recognizes that there exists a large number of governmental mandates and regulatory measures regarding workplace safety, hours and overtime requirements, pensions, discrimination, family leave, and the like. Under a system of conditional deregulation, the default for all (or nearly all) firms would be that they are covered by the full extent of these labor market regulations. These requirements would be divided into those that are waivable and those non-waivable. Non-waivable rights would include some minimum set of standards (say, with respect to discrimination or safety) that could not be waived by any employer. Conditional deregulation would permit employers to be exempt from the waivable set of regulatory standards and be subject only to the mini- 
mum standards if they voluntarily adopt alternative regulatory systems with employee oversight and approval.

In order to waive the regulations or "deregulate" workplace standards, firms must have in place independent worker committees to perform the approval and oversight functions. For firms that are unionized, the union would provide the employee voice that has authority to waive government standards beyond the minimum (the employer must also approve the waiver). For the majority of employers who are not unionized, worker committees or councils would have to be created that would have authority to approve the waiver on behalf of workers. A contentious issue would be the nature of the worker committees and the permissible employer role. Unlike Levine, we would argue for abolishment or major reform of 8(a)(2) of the NLRA, which restricts the creation of and role for worker associations or groups other than traditional labor unions. We would permit a reasonably active role for the firm in setting up such worker councils, as long as they met minimum government requirements regarding independence, democratic choice of worker spokespersons, secret balloting on key issues, and antidiscrimination provisions protecting workers active in the worker associations. ${ }^{33}$

An important benefit of such an approach would be that it would spur the establishment of worker associations throughout the private sector and provide a vehicle that might enhance worker voice and cooperation between management and its work force. In establishments where worker associations are formed, it is likely that their major role will be to enhance worker voice. Such worker groups, however, can also serve as a vehicle to transfer rents or quasi-rents from shareholders to workers, since their approval of waiving workplace regulations is likely to be conditional on the receipt of monetary or non-monetary gains. However, because the employer has the option of staying with the national regulatory standard, this makes it likely that any gains to workers through rent transfer will be less than the additional gains to shareholders from deregulation. In short, such a policy encourages value-enhancing choices by the firm and workers, while constraining the extent of rent seeking.

Adoption of a conditional deregulation scheme, as outlined above, would be likely to accelerate passage by Congress of waivable labor market mandates and employment regulations. Moreover, such regulations would likely set more stringent standards and contain fewer exemptions (based on company size and the like) than has been the case in the past. More stringent regulations could be quite costly if there were no option to waive coverage. Given the availability of an opt-out, however, those establishments where regulations would prove costly are the ones most likely to agree on a mutuallypreferred set of alternative standards. The hope is that over time more establishments would create workers' associations that evolve along lines that provide an effective vehicle for worker voice, encourage cooperation between management and its employees, and facilitate value-enhancing changes in the workplace. The widespread creation of worker associations may also provide the impetus for both fundamental changes in and growth of labor unions in the private sector.

Changing the Labor Law Default. The second approach we consider would shift the labor law default from its current setting of not unionized to some alternative invok- 
ing a governance structure providing independent worker voice. The default structure could be waived or replaced following the joint approval of workers and management. A point to emphasize is that choices of a labor law default and an employment regulation standard matter a lot, even where there exist procedures to modif y those outcomes (Sunstein, 2000). For example, current labor law has a nonunion default, but allows majority worker choice of union representation. Imagine the opposite, with union representation the default, but workers free to reject representation by majority vote. In a frictionless system in which preferences are unaffected by the initial allocation, one might expect the two systems to produce the same outcomes. ${ }^{34}$

Of course the NLRA union certification process is far from frictionless. Even absent such frictions, however, evidence from behavioral economics (Sunstein, 2000) indicates that workers would be more likely to stick with their initial endowment (collective bargaining) than would have chosen to adopt it through free elections. Stated alternatively, were union coverage the workplace default, far more than 10 percent of private sector workers would remain unionized, even with frictionless decertification elections.

What might be the outline of an alternative labor law default? It is not clear a priori what would be the optimal default for a governance structure. But the choice is important, since many workplaces will retain the default standard. Our own preference would be a default that sets into motion the creation of some form of independent worker association, although not one with full collective bargaining rights. As part of any default set of rights, workers would retain their current right to form independent labor unions (without management approval). It would be important that $8(\mathrm{a})(2)$ of the NLRA be abolished or crippled. This would permit workers and firms to choose from among a range of choices beyond either a traditional labor union or a nonunion workplace with no formal voice mechanism. We would also like the default mechanism to designate some standardized procedure by which workers and management might discuss, negotiate, and approve mutually beneficial changes.

Whatever the choice of a default, it will not function well in some (or many) workplaces. The same is true for our current labor law default. In these workplaces, the employer and workers (either in the form of unions or worker associations) have incentive to move away from the default and develop proposals for participatory workplace governance structures that are value enhancing. Our proposal for a change in the employment relations default can be combined with Levine's proposal for conditional deregulation. One might have a default that establishes a relatively independent worker association in the workplace. Management and workers could then make a joint decision to opt-out of waivable federal workplace standards.

A benefit of changing the default is that it would encourage management, workers, and workers' agents (be they traditional unions or worker associations) to communicate, negotiate, and arrive at alternatives that make all parties better off relative to the default. It is clear that the current labor law default provides little incentive for management or traditional unions to develop value-enhancing alternatives. An alternative 
default that permitted greater flexibility, be it through conditional deregulation or nonunion worker associations, would encourage value-enhancing innovations.

Obviously, any major change in employment law and the default governance structure requires thorough analysis and careful design. ${ }^{35}$ The actual working of such a system will be determined in no small part by the way it evolves within the workplace, courts, and regulatory agencies. For example, a shift in the default away from the nonunion standard toward one emphasizing collective voice could readily shift too much power to incumbent workers (insiders), leading to compensation levels inconsistent with full employment. Our preference would be for a default that limits the ability of worker associations or works councils to appropriate rents, but on the other hand encourages communication and the evolution of value-enhancing arrangements (for a discussion of such issues, see Freeman and Lazear, 1995).

We reiterate that the most likely prospect for the future, or at least the near future, is not some variant of the proposals discussed above, but continuation of the status quo. It is simply not politically possible to get from where we are currently to a major change in employment law. Such major changes cannot occur politically until there is strong dissatisfaction with our current system and a consensus that change is likely to be beneficial. While such a consensus may exist among legal and industrial relations scholars, it does not exist among the public at large. We do not know what economic and social changes might precipitate the emergence of a consensus for major changes in the workplace.

\section{Conclusion}

The outlook for private sector unions, at least in their current form, is bleak. The attrition rate of union jobs (and workers) exceeds the rate at which workers are being organized. Private sector union density, currently below 10 percent, will continue its decline until it reaches a sustainable level. A marked improvement in the outlook for private unionism will require a major shift in worker and public attitudes toward workplace collective action, a substantial change in what unions do, or major innovations in policy regarding workplace governance structures. None of these is likely in the immediate future.

An important determinant of management resistance to unions and employment change in unionized firms is how unions affect firm profitability and workplace performance. All evidence points to lower profits under unionism, with union effects on productivity being insufficient to off set what are substantial wage premiums. Surprisingly, there is no consensus as to how union wage premiums have changed as private sector union density has declined. For a given level of labor demand, there will an inverse relationship between the union wage premium and membership. ${ }^{36}$ If the demand for union labor is shifting downward, however, there should be a positive relationship, with the wage premium falling during a period of declining union density.

A contribution of this paper is the presentation of time-consistent estimates of the private sector union wage premium for the years 1973-1999, based on work in Hirsch and Schumacher (2000). Several important results emerge from this research. First pri- 
vate sector union wage premiums are larger than public sector premiums, but over time public sector premiums and the share of union members in the public sector have increased. Hence, stability in the economy-wide union premium since the early 1980 s masks what has been a decline in the private sector premium. Second, Census hot-deck procedures used to impute the earnings of non-respondents in the CPS cause a substantial downward bias in measures of the union-nonunion wage gap. Unbiased union premiums are several percentage points higher than those commonly estimated and presented in the research literature. Changes over time in the identification of imputed earners in the CPS research files and changes in the proportion of workers with earnings imputed have led to misleading estimates of changes in the union premium. Contrary to much previous evidence, union wage premiums were as high or higher in the 1980s as they had been in the late 1970s. Changes in the CPS beginning in 1994 increased the number of workers with earnings imputed. Thus, downward bias in union premium estimates since 1994 has been particularly severe.

A third finding is that there exists large differences in the trend in union premiums depending on whether one focuses on unadjusted (raw) wage figures or adjusted (regression based) wage gaps, and whether or not one uses the CPS or ECI. Focusing on the change in the union premium between 1983 and 1999, we find a substantial narrowing of the union-nonunion gap based on both unadjusted CPS earnings and published ECI figures (the ECI controls for changes in the industry and occupation mix but not other worker characteristics). Time-consistent CPS regression analysis controlling for worker characteristics, however, indicates that narrowing of the private sector union premium has been rather modest. We conclude that our regression analysis provides the preferred measure of the wage gap.

The modest decline in the union premium during a period in which union density fell sharply implies that union rank and file have placed a heavy emphasis on maintaining wages, even though this accelerates the loss in membership. An emphasis on rent seeking in an increasingly competitive world guarantees that labor unions, at least in their traditional form, will continue their decline in the private sector. For the more than 90 percent of private sector workers who are not union members, worker voice and participation in the workplace are sub-optimal. At the same time, there has been an increased reliance on governmental regulations and mandates coupled with a litigious enforcement process.

We argue that it is time to explore alternative workplace governance structures that are likely to be value-enhancing, that increase worker voice and participation, that constrain rent-seeking behavior, and that can vary across heterogeneous workplaces and over time. We outline two possibilities - conditional deregulation and changing the governance default in the workplace. Conditional deregulation (Levine, 1995) would permit an employer, with the approval of an independent worker association, to waive some subset of federal workplace regulations. The second proposal would change the governance default from one of no union to a default with some form of independent workers' association. Such an association would be set up to provide voice but to have limited rent-seeking power (workers would retain current rights to elect traditional 
union representation). Alternative workplace governance rules could then be selected with the mutual agreement of the worker association and employer.

Perhaps in the not so distant future, there will emerge a consensus among union leaders and policy makers that unionism as we know it will not rebound and that an expanded role for worker voice in the private sector can occur only if there is adoption and experimentation with new forms of worker representation. At that point, it may be possible for politicians, business representatives, and organized labor to design and rally public support for alternative forms of workplace governance. A movement in this direction may lead not only to improvements in social welfare, but also to a revitalization of the labor union movement, albeit in a substantially altered form. Absent such a consensus, we are likely to see a continued marginalization of unions in the private sector, increasing governmental regulation of labor markets, and an underprovision of value-enhancing voice in the workplace.

\section{NOTES}

*We particularly appreciate detailed suggestions received from Bruce Kaufman, as well as comments from Jeffrey Hirsch and participants at the Roundtable on Labor Law, University of Pennsylvania, Institute for Law and Economics. Henry Farber kindly provided data for Figures 3 and 4.

'For example, see Freeman (1997), Farber and Westem (2000), and Lipset and Katchanovski (2001).

${ }^{2}$ Writing such a paper reminds one of physicist Niels Bohr's comment: "Prediction is difficult, particularly of the future" (quoted in Levine, 1995, p. 161). It is difficult enough to describe and understand the past using accepted research methods and building on past research. Predicting the future is far less reliable. Just as few predicted the meteoric rise in unionism in the middle third of last century, there were few during the 1950s and 1960s predicting that private sector unionism would return to pre-NLRA levels by the end of the century (Kauf man, 2001).

${ }^{3}$ The equivalent density figures among all private sector wage and salary workers (including agricultural) are 24.2 percent, 16.5 percent, and 9.4 percent (Hirsch and Macpherson, 2000, Table lb, p. 12). The percent of private nonagricultural workers covered by a collective bargaining agreement are 18.8 percent in 1983 and 10.3 percent in 1999 (coverage figures are not available until 1977). Unless noted otherwise, all figures on unionization were computed from the Current Population Survey (CPS) using methods identical to those by the Bureau of Labor Statistics (BLS), as seen in January issues of Employment and Earnings. For more detail, see the Hirsch and Macpherson Data Book, published annually by the Bureau of National Affairs.

${ }^{4}$ See, also, figures presented in Chaison and Dhavale (1990). Farber and Western (2000) carefully analyze the timing of the drop in certification elections. They conclude that the break in the election series began in the month just prior the PATCO strike and well before the Dotson-led NLRB board. Although they reject the PATCO strike as the proximate cause of the decline, they do not offer an explanation for the speed and magnitude of the drop. The early-1980s decline in organizing coincides with the run-up in the value of the dollar and a recession that hit particularly hard the goods-producing sector.

${ }^{5} \mathrm{~A}$ high initial win rate following passage of the NLRA was expected since many election units had overwhelming worker support for representation. Over time, most election units were likely to have mixed preferences.

${ }^{6}$ Cited in Farber and Western (2000) is evidence from Weiler that the fraction of union wins resulting in first contracts fell from 86 percent in 1955 to 63 percent in 1980. The Dunlop Commission reports that a third or more certified units fail to reach a first contract. 
${ }^{7}$ Farber and Western conclude that steady-state density is 2.1 percent. They have adjusted their union figures to reflect reporting error, which causes union density to be overstated (understated) when true density is less (greater) than half. They rely on a misclassification rate reported by Card (1996) of 2.7 percent for union and nonunion workers. Bias would be zero if density were 50 percent, while upward bias in reported density would increase to a limit of 2.7 percent as true density reached zero. A "true" rate of 2.1 percent corresponds to a "reported" or measured density rate of about 4.5 .

${ }^{8}$ For a surveys and analysis, see Addison and Hirsch (1989), Booth (1995), Hirsch (1997), and Kuhn (1998). Were union wage premiums simply a tax on above-normal profits, their real effects might be small. But the weight of the evidence is that unions tax the normal returns to capital and have real effects on investment and employment growth. A recent survey has measured the views of labor economists at top universities. In response to the question: "What is your best estimate of the percentage impact of unions on the productivity of unionized companies" the median response was zero and mean response 3.1 percent (Fuchs, Krueger, and Poterba, 1998, pp. 1392, 1418). Absent a substantial productivity effect, union wage premiums lead to lower profitability.

${ }^{9}$ For an overview of the literature on deregulation and earnings, see Peoples (1998).

${ }^{10}$ Large union-nonunion differences in performance need not imply large effects economy-wide, since resources shift from nonunion to union sectors.

"Quoting Kuhn (1998, p. 1039): "Like successful viruses, unions are smart enough not to kill their hosts."

${ }^{12}$ An exception is construction, where the 1977 Kiewit decision allowing "double-breasting" (nonunion subsidiaries of union contractors) played a major role in an unusually sharp decline in construction union density (Allen, 1994).

${ }^{13}$ For an analysis of the debate and views surrounding passage of the NLRA, see Kaufman (1996).

${ }^{14}$ Implicit in this argument is that employment regulation and workplace protection offered by unions are substitutes, in the sense that greater government provision reduces demand for union organizing. This view need not be inconsistent with the finding that unionization and regulation are supplementary in the production of workplace safety enforcement (Weil, 199l) and workers' compensation claims (Hirsch et al., 1997).

${ }^{15}$ For attempts at measuring the substitution between government policies and changes in union membership, see Neumann and Rissman (1984) and Stepino and Fiorito (1986). For a survey of the economic effects of workplace mandates and employment regulation, see Addison and Hirsch (1997).

${ }^{16} \mathrm{We}$ say unlikely for three reasons. First, union wages positively affect density through their impact on nonunion worker preferences for organizing. But union wages negatively affect density through their impact on management opposition to organizing and through employment in existing union establishments. Second, there is typically a queue or excess supply of qualified workers who would like to obtain union jobs, but cannot. This implies that were union wages lower, employment and membership would increase. Third, the U.S. has the lowest and most rapidly declining union density among OECD countries, while having the highest union wage premium (Blanchflower and Freeman, 1992), supporting the thesis of a negative wage-density relationship.

${ }^{17}$ This is the relationship emphasized by Linneman et al. (1990), who find the largest declines in union density in industries with the highest union premiums.

${ }^{18} \mathrm{~A}$ shift to $D_{L}^{\prime}$ does not necessarily lead to a lower preferred wage. For example, if the median union member is not threatened by unemployment and acts in a selfish manner, union wage demands may not decline. Empirical evidence in coal and newspaper printing, however, suggests that "monopoly unions" give a considerable weight to employment (Booth, 1995, pp. 101-108). Moreover, real-world outcomes are determined by bargaining rather than a monopoly union, making it even more likely that a downward demand shift results in a lower union wage.

${ }^{19}$ Union density may also decrease owing to declining worker preferences for collective bargaining. This need not affect the wage premium, apart from the effect that industry density has on union bargaining power (see below). 
${ }^{20}$ The change from $C$ to $C^{\circ}$ shifts the contract zone down in wage space, leading to a lower contract wage if relative bargaining power remains unchanged.

${ }^{21}$ Union threat effects should be nonlinear, with weak effects on wages at very low and high levels of density (Comeo and Lucifora, 1997).

${ }^{22}$ Log differentials are similar to percentage differences at absolute values smaller than about .15. Log differentials can be converted to (approximate) percentages by $[\exp (d)-1] 100$, where $d$ is the log differential. We ignore problems with respect to the estimation of union premiums, such as specification, the endogeneity of union status, unmeasured worker and job attributes, and employer-employee selection on skills and preferences (Card, 1996; Hirsch and Schumacher, 1998).

${ }^{23}$ Estimates of gender-specific means above the cap for 1973-1999 are shown in Hirsch and Macpherson $(2000$, p. 6$)$. These values are approximately 1.5 times the cap, with smaller female means and modest growth over time.

${ }^{24}$ Wage gap estimates with respect to match criteria (e.g., schooling, gender, occupation) are not biased.

${ }^{25} \mathrm{Absent}$ adjustment for the imputed eamings bias, we obtain unadjusted union wage gap estimates of 345 in 1983 and .210 in 1999 (a .135 log point decline), as compared to the differentials .386 and .276 reported in Figure 6.

${ }^{26}$ The downward bias from the Census imputation procedure is largest in years since 1994, so our correction for the bias leads not only to higher union wage gap estimates, but a smaller decline in the gap than would result absent the correction. Despite the seeming clarity of these results, they stand in contrast to the view that the union wage gap shows little trend (Blanchflower 1999; Bratsberg and Ragan, 1999). Hirsch and Macpherson (2000) find a small change in the economy-wide wage gap, as compared to a decline in the private sector gap. The seeming constancy of the overall gap is the result of an increasing public sector union differential coupled with an increasing proportion of union members over time being in the public sector.

${ }^{27}$ See the note to Figure 6 for details of how the ECI differentials are calculated. Katz and Krueger (1999, BPEA, Table 14) cite evidence on ECI total compensation growth for union and nonunion workers.

${ }^{28}$ Bratsberg and Ragan (1999) use a more detailed industry breakdown and find lower dispersion in the CPS wage premium, but little change in the aggregate level. The ECI also provides broad breakdowns for goodsproducing versus service-producing sectors and manuf acturing versus nonmanuf acturing, each classified by union status. Relative union-nonunion wage growth differs little across these broad sectors, again indicating that employment shifts and industry heterogeneity play a minor role in accounting for changes over time in the union wage gap.

${ }^{29}$ This sentiment is expressed in a recent Business Week column: "A whole generation of unionists settled for this strategy: protecting senior unionized workers, knowing that their numbers would diminish over time" (Kuttner, 2000).

${ }^{30}$ Empirical evidence on the eff ects of workplace mandates is surveyed in Addison and Hirsch (1997). Discussion of labor law reforms is beyond the scope of our paper. Among the recommendations proposed by the recent Dunlop Commission were: narrowing the definition of supervisory and managerial workers who are exempt from the NLRA, shortening the time between the call for union elections and conduct of the elections, increased access of workers to union organizers, procedures such as mediation to facilitate newly certified unions to achieve first contracts, and fast injunctive relief against discriminatory action by employers. For examples of labor law reforms that generally promote "value-added" unionism, see Estreicher (1996).

${ }^{31}$ Such reforms might include profit sharing or plant-level bargaining, each of which might makethe demands of the median union member more sensitive to firm performance (we thank Bruce Kaufman for these suggestions).

${ }^{32}$ Abowd (1989b) defines the value of the "enterprise" as the sum of firm market value plus worker rents. For a change to be value enhancing to the parties, we mean that the value of the enterprise has increased. 
${ }^{33}$ The TEAM Act, passed by Congress but vetoed by President Clinton in July 1996, would have limited the scope of 8(a)(2) and allowed employer-organized and employer-funded worker participation groups in nonunion plants and offices. Levine would continue protections that prevent creation of "company unions." For evidence on how company unions worked prior to passage of the NLRA, see Kauf man (2000).

${ }^{34} \mathrm{We}$ ignore the issue of obtaining first contracts, regarding ma jority approval as leading to union coverage.

${ }^{35}$ Relevant will be the experience that other countries have had with worker councils and alternative forms of organization. For a recent analysis and references, see Addison et al. (2000).

${ }^{36}$ As noted previously, when settlements are on a vertical contract curve this holds only in the long run.

\section{REFERENCES}

Abraham, Katharine G., James R. Spletzer, and Jay C. Stewart. "Why Do Different Wage Series Tell Different Stories?" American Economic Review Papers and Proceedings 89 (May 1999): 34-39.

Abowd, John M. "The Effects of Differential Unionization Environments on the Pattern of Interindustry Investment." Mimeographed, Cornell University, June, 1989a.

. "The Effect of Wage Bargains on the Stock Market Value of the Firm." American Economic Review 79 (September 1989b): 774-800.

Addison, John T. and Barry T. Hirsch. "Union Effects on Productivity, Profits, and Growth: Has the Long Run Arrived?" Journal of Labor Economics 7 (January 1989): 72-105.

"The Economic Effects of Employment Regulation: What Are the Limits?" In Government Regulation of the Employment Relationship. Bruce Kaufman, ed. Madison, Wisc.: Industrial Relations Research Association, 1997, pp. 125-78.

Addison, John T., Stanley Siebert, Joachim Wagner, and Xiangdong Wei. "Worker Participation and Firm Performance: Evidence from Germany and Britain." British Journal of Industrial Relations 38 (March 2000): 7-48.

Allen, Steven G. "Developments in Collective Bargaining in Construction in the 1980s and 1990s." In Contemporary Collective Bargaining in the Private Sector. Paula B. Voos, ed. Madison, Wisc.: Industrial Relations Research Association, 1994, pp. 411-46.

Blanchflower, David G. "Changes Over Time in Union Relative Wage Effects in Great Britain and the United States." In The History and Practice of Economics. Essays in honor of Bernard Corny and Maurice Peston, Vol. 2. Sami Daniel, Philip Arestis and John Grahl, eds. Northhampton, Mass.: Edward Elgar, 1999, pp. 3-32.

and Richard B. Freeman. "Unionism in the United States and Other Advanced OECD Countries." Industrial Relations 31 (Winter 1992): 56-79.

Booth, Alison. The Economics of the Trade Union. Cambridge: Cambridge University Press, 1995.

Bosworth, Barry and George L. Perry. "Productivity and Real Wages: Is There a Puzzle?" Brookings Papers on Economic Activity (1 1994): 317-44.

Bratsberg, Bernt and James F. Ragan Jr. "Changes in the Union Wage Premium by Industry - Data and Analysis.” Kansas State University, June 1999.

Card, David. "The Effect of Unions on the Structure of Wages: A Longitudinal Analysis." Econometrica 64 (July 1996): 957-79.

Chaison, Gary N. and Dileep G. Dhavale. "A Note on the Severity of the Decline in Union Organizing Activity." Industrial and Labor Relations Review 43 (April 1990): 366-73. 
Comeo, Giacomo and Claudio Lucifora. "Wage Formation under Union Threat Effects: Theory and Empirical Evidence." Labour Economics 4 (September 1997): 265-92.

Dickens, William T. and Jonathan S. Leonard. "Accounting for the Decline in Union Membership, 1950-1980." Industrial and Labor Relations Review 38 (April 1985): 323-34.

Dunne, Timothy and David A. Macpherson. "Unionism and Gross Employment Flows." Southern Economic Journal 60 (January 1994): 727-38.

Estreicher, Samuel. "Freedom of Contract and Labor Law Reform: Opening Up the Possibilities for ValueAdded Unionism." New York University Law Review 71 (June 1996): 827-49.

Farber, Henry S. "The Decline of Unionization in the United States: What Can Be Learned from Recent Experience?” Journal of Labor Economics 8 (January 1990, Part 2): S75-105.

. "Union Success in Representation Elections: Why Does Unit Size Matter?" Industrial and Labor Relations Review 54 (January 2001): 329-48.

and Alan B. Krueger. "Union Membership in the United States: The Decline Continues." In Employee Representation: Alternatives and Future Directions. Bruce E. Kaufman and Morris M. Kleiner, eds. Madison, Wisc.: Industrial Relations Research Association, 1993, pp. 105-34.

Farber, Henry S. and Bruce Western. "Round Up the Usual Suspects: The Decline of Unions in the Private Sector, 1973-1998." Industrial Relations Section, Princeton University. Working Paper \#437, April 2000.

Flanagan, Robert J. Labor Relations and the Litigation Explosion. Washington, D.C.: Brookings Institution, 1987.

Freeman, Richard B. "Contraction and Expansion: The Divergence of Private Sector and Public Sector Unionism in the United States." Journal of Economic Perspectives 2 (Spring 1988): 63-88.

. "Spurts in Union Growth: Defining Moments and Social Processes." National Bureau of Economic Research Working Paper 6012, April 1997.

and Morris M. Kleiner. "Do Unions Make Enterprises Insolvent?" Industrial and Labor Relations Review 52 (July 1999): 510-27.

Freeman, Richard B. and Edward P. Lazear. "An Economic Analysis of Works Councils." In Works Councils: Consultation, Representation, and Cooperation. Joel Rogers and Wolfgang Streeck, eds. Chicago: University of Chicago Press (NBER), 1995, pp. 27-50.

Freeman, Richard B. and James L. Medoff. "The Impact of the Percent Organized on Union and Nonunion Wages." Review of Economics and Statistics 63 (November 1981): 561-72.

. What Do Unions Do? New York: Basic Books, 1984.

Freeman, Richard B. and Joel Rogers. What Workers Want. Ithaca, N.Y.: Cornell University Press, 1999.

Fuchs, Victor R., Alan B. Krueger, and James M. Poterba. "Economists' Views about Parameters, Values, and Policies: Survey Results in Labor and Public Economics." Journal of Economic Literature 36 (September 1998): 1387-425.

Hirsch, Barry T. "Unionization and Economic Performance: Evidence on Productivity, Profits, Investment, and Growth." In Unions and Right-to-Work Laws. Fazil Mihlar, ed. Vancouver, B.C.: The Fraser Institute, 1997, pp. 35-70.

and David A. Macpherson. "Earnings and Employment in Trucking: Deregulating a Naturally Competitive Industry." In Regulatory Reform and Labor Markets. James Peoples, ed. Norwell, Mass.: Kluwer Academic Publishing, 1998, pp. 61-112.

Hirsch, Barry T. and David A. Macpherson. "Earnings, Rents, and Competition in the Airline Labor Market." Journal of Labor Economics 18 (January 2000): 125-55. 
Union Membership and Earnings Data Book: Compilations from the Current Population Survey(2000 Edition). Washington, D.C.: Bureau of National Affairs, 2000.

and J. Michael DuMond. "Workers' Compensation Recipiency in Union and Nonunion Workplaces.” Industrial and Labor Relations Review 50 (January 1997): 213-36.

Hirsch, Barry T. and Schumacher, Edward J. “Unions, Wages, and Skills.” Journal of Human Resources 33 (Winter 1998): 201-19. 2000 .

“Earnings Imputation and Bias in Wage Gap Estimates.” Unpublished Manuscript, February

Katz, Lawrence F. and Alan B. Krueger. "The High-Pressure U.S. Labor Market of the 1990s." Brookings Papers on Economic Activity 1 (1999): 1-65.

Kaufman, Bruce E. "Why the Wagner Act?: Reestablishing Contact with Its Origins.” In Advances in Industrial and Labor Relations. David Lewin, Bruce E. Kauf man, and Donna Sockell, eds. Vol. 7. Greenwich, Conn.: JAI Press, 1996.

"Nonunion Employee Representation in the Pre-Wagner Act Years: A Reassessment." In Nonunion Employee Representation: History, Contemporary Practice, and Policy. Bruce E. Kaufman, and Daphne Taras, eds. Armonk, N.Y.: M.E. Sharp, 2000, pp. 21-60.

“"The Future of U.S. Private Sector Unionism: Did George Barnett Get It Right After All?" Journal of Labor Research 22 (Summer 2001): 433-57.

"An Economic Analysis of Employee Representation." In Nonunion Employee Representation: History, Contemporary Practice, and Policy. Bruce E. Kaufman, and Daphne Taras, eds. Armonk, N.Y.: M.E. Sharp, 2000, pp. 149-75.

Krueger, Alan B. “Measuring Labor's Share.” American Economic Review Papers and Proceedings 89 (May 1999): 45-51.

Kuhn, Peter. "Unions and the Economy: What We Know; What We Should Know." Canadian Journal of Economics 31 (November 1998): 1033-56.

Kuttner, Robert. "Verizon's Crash Course in High-Tech Unionism.” Business Week, September 11, 2000.

LaLonde, Robert J., Gérard Marschke, and Kenneth Troske. "Using Longitudinal Data on Establishments to Analyze the Effects of Union Organizing Campaigns in the United States." Annales d' Économie et de Statistique No. 41/42 (1996): 155-85.

Levine, David I. Reinventing the Workplace: How Business and Employees Can Both Win. Washington, D.C.: Brookings Institution, 1995.

and Laura D' Andrea Tyson. "Participation, Productivity, and the Firm's Environment." In Paying for Productivity: A Look at the Evidence. Alan S. Blinder, ed. Washington, D.C.: Brookings Institution, 1990, pp. 183-237.

Linneman, Peter D., Michael L. Wachter, andWilliam H. Carter. "Evaluating the Evidence on Union Employment and Wages." Industrial and Labor Relations Review 44 (October 1990): 34-53.

Lipset, Seymour Martin and Ivan Katchanovski. “The Future of Private Sector Unions in the U.S.” Journal of Labor Research 22 (Spring 2001): 229-44.

Neumann, George R. and Ellen R. Rissman. “Where Have All the Union Members Gone?”Journal of Labor Economics 2 (April 1984): 175-92.

Peoples, James. "Deregulation and the Labor Market.” Journal of Economic Perspectives 12 (Summer 1998): 111-30.

Riddell, W. Craig. "Unionization in Canada and the United States: A Tale of Two Countries." In Small Differences That Matter: Labor Markets and Income Maintenance in Canada and the United States. David Card and Richard B. Freeman, eds. Chicago: University of Chicago Press (NBER), 1993, pp. 109-47. 
Rosen, Sherwin. "Trade Union Power, Threat Effects, and the Extent of Organization." Review of Economic Studies 36 (April 1969): 185-96.

Schneider, Thomas J. "The Choice is Simple: A Strong Independent Labor Movement or Federal Government Regulation." In Government Regulation of the Employment Relationship. Bruce Kaufman, ed. Madison, Wisc.: Industrial Relations Research Association, 1997, pp. 521-31.

Stepina, Lee P. and Jack Fiorito. "Toward a Comprehensive Theory of Union Growth and Decline." Industrial Relations 25 (Fall 1986): 248-64.

Sunstein, Cass R. "Human Behavior and the Law of Work." John M. Olin Law \& Economics Working Paper 100 (2nd Series), University of Chicago, June 2000.

Troy, Leo. "Convergence in International Unionism, etc.: The Case of Canada and the USA." British Journal of Industrial Relations 30 (March 1992): 1-43.

“U.S. and Canadian Industrial Relations: Convergent or Divergent." Industrial Relations 39 (October 2000): 695-713.

and Neil Sheflin. U.S. Union Sourcebook: Membership, Finances, Structure, Directory. West Orange, N.J.: Industrial Relations Data Information Services, 1985.

Weil, David. "Enforcing OSHA: The Role of Labor Unions." Industrial Relations 30 (Winter 1991): 20-36.

Weiler, Paul C. Governing the Workplace: The Future of Labor and Employment Law. Cambridge, Mass.: Harvard University Press, 1990. 